\title{
EFFECT OF 1,1-DIPHENYL-3-PIPERIDINOBUTANOL HYDROCHLORIDE (ASPAMINOL) ON THE STIMULI-INDUCED CALCIUM UPTAKE IN RAT BRAIN SYNAPTOSOMES
}

\author{
Fukio KONNO and Issei TAKAYANAGI* \\ Department of Chemical Pharmacology. Toho University School of Pharmaceutical Sciences, \\ Miyama, Funabashi, Chiba 274, Japan
}

Accepted July 30, 1981

\begin{abstract}
Effects of 1.1-diphenyl-3-piperidinobutanol hydrochloride (Aspaminol), a nonspecific smooth muscle relaxant, on the uptake of calcium in the synaptosomes of rat brain were studied, using two stimuli i.e. high $\mathrm{KCl}$ and ATP. We also studied the effect of Aspaminol on the analgesic response of rat hindpaw using the Randall-Sellito test. The addition of Aspaminol inhibited the stimuli-induced calcium uptake in a concentration dependent manner. Aspaminol inhibited the high $\mathrm{KCl}$ induced calcium uptake competitively against the external calcium concentration. These findings suggest that Aspaminol may act on the surface of the synaptosomal membranes. In case of ATP stimulated calcium uptake, Aspaminol reduced the rate of uptake and maximal level of the synaptosomal calcium, and did not appear to have any effect on the rate of calcium release. These findings suggest that the inhibitory effect of Aspaminol can be mainly attributed to inhibition of the calcium influx, but not to acceleration of calcium efflux. In the five weeks old rats. Aspaminol did not influence the responses in the paw pinch test, but, in the weanling rats (about three weeks old). Aspaminol had a slight effect on the responses in the paw pinch test. This discrepancy may be due to difficulties in passing through the blood-brain barrier. Our findings suggest that a certain relationship may exist between the analgesic effect and the calcium uptake in the synaptosomes.
\end{abstract}

The concentration of free calcium outside and within neurons plays an important role in the functioning of the nervous systems. The release of neurotransmitters at the nerve endings is dependent on calcium, and appears to be triggered by a rise in the cytoplasmic calcium level (1).

Recently, numerous studies have shown that synaptosomes (pinched-off nerve terminals isolated from brain homogenate) resemble intact tissue in transport $(2,3)$ and

*To whom reprint requests should be addressed. metabolic processes $(4,5)$, and thus synaptosomes should afford on excellent model system for examining calcium disposition at the nerve endings.

Numerous investigations have indicated a role for calcium in the production of analgesia by opiates. Morphine-induced analgesia was inhibited by the administration of calcium (6) and enhanced by a calcium ionophore. X537A (7). Furthermore, a specific inhibition by opiates of calcium uptake in the synaptosomes has been described (8-10). Moreover, it has been suggested that 
morphine blocks the release of neurotransmitters by decreasing calcium influxes. These findings indicate that a close relationship may exist between the analgesic effect and calcium movement.

Nachshen and Braustein (11) and Ichida et al. (12) showed that verapamil and $D 600$ inhibited the calcium uptake in the synaptosomes from rat brain. Verapamil and D 600 also inhibited the calcium uptake in smooth muscle (13) and in microsomal fractions (14). Takayanagi et al. found that 1.1-diphenyl-3-piperidinobutanol hydrochloride (Aspaminol), a nonspecific smooth muscle relaxant, also inhibited the calcium uptake in smooth muscle (15) and in microsomal fractions (14, 16).

We attempted to determine whether or not Aspaminol inhibits the stimuli-induced calcium uptake in the synaptosomes and whother or not this drug possesses the analgesic responses.

\section{MATERIALS AND METHODS}

Preparations of synaptosomes: Synaptosomes were prepared from brain homogenates of male Wistar strain rats weighing 150 to $250 \mathrm{~g}$. using a discontinuous Ficoll gradient centrifugation, according to a modification of the procedure of Cotman and Matthews (17). Homogenization of brains (except the cerebellum) was carried out in 9 volumes of ice-cold $0.32 \mathrm{M}$ sucrose, $5 \mathrm{mM} \quad \mathrm{N}$-2-hydroxyethyl piperazine-N'-2 ethanesulfonic acid (HEPES) buffer, brought to $\mathrm{pH} 7.4$ at $25^{\circ} \mathrm{C}$ by titration with Tris base, in a glass homogenizer with a Teflon pestle. The homogenate was centrifuged at $1.000 \times \mathrm{g}$ for $10 \mathrm{~min}$. The supernatant was centrifuged at $17.000 \times \mathrm{g}$ for $10 \mathrm{~min}$. The resultant pellet was resuspended in fresh $0.32 \mathrm{M}$ sucrose-5 $\mathrm{mM}$ HEPES buffer (half to the volume decanted) and again centrifuged at $17.000 \times \mathrm{g}$ for $10 \mathrm{~min}$. The pellet from this spin (crude mitochondrial fraction) was resuspended in $0.32 \mathrm{M}$ sucrose $-5 \mathrm{mM}$ HEPES buffer and lavered on top of a discontinuous gradient composed of $15 \mathrm{ml}$ of $7.5 \%(\mathrm{w} / \mathrm{v})$ Ficoll on top of $15 \mathrm{ml}$ of $12 \%$ $(w / v)$ Ficoll, both in $0.32 \mathrm{M}$ sucrose, and tho preparation centrifuged at $65,000 \times g$ for $50 \mathrm{~min}$ in a Hitachi ultracentrifuge with a swing bucket rotor, RPS 27-2. After centrifugation, the material between the $7.5 \%$ and $12 \%$ Ficoll interface (Synaptosomal fraction) was harvested with a Pasteur pipette and, in case of potassium stimulated ${ }^{45} \mathrm{Ca}^{2+}$ uptake, was diluted with about 8 volumes of ice-cold $\mathrm{Ca}^{2+}$-free physiological salt solution containing $132 \mathrm{mM} \mathrm{NaCl}, 5 \mathrm{mM}$ $\mathrm{KCl}, 1.2 \mathrm{mM} \mathrm{NaH} \mathrm{PO}_{4}, 1.3 \mathrm{mM} \mathrm{MgCl}_{2}$, $10 \mathrm{mM}$ glucose and $20 \mathrm{mM}$ Tris buffered to $\mathrm{pH} 7.4$ at $25^{\circ} \mathrm{C}$ by titration with maleic acid, or, in case of ATP stimulated ${ }^{45} \mathrm{Ca}^{2+}$ uptake, diluted with about 2 volumes of ice-cold $0.32 \mathrm{M}$ sucrose. The dilution was made by progressive addition of aliquots of the ice-cold $\mathrm{Ca}^{2+}$-free physiological salt solution or $0.32 \mathrm{M}$ sucrose over a $15 \mathrm{~min}$ period. The diluted suspension with $\mathrm{Ca}^{2+}$ free physiological salt solution was then centrifuged at $9.000 \times \mathrm{g}$ for $10 \mathrm{~min}$, and with $0.32 \mathrm{M}$ sucrose was then centrifuged at $100,000 \times \mathrm{g}$ for $30 \mathrm{~min}$. The resultant pellet was resuspended in each ice-cold preincubation modium in a glass homogenizer with a Teflon pestle at lowest speed, and kept on ice prior to the incubation, which was always carried out the same day. All procedures were carried out below $4^{\circ} \mathrm{C}$. These synaptosomal suspensions were used for determination of ${ }^{45} \mathrm{Ca}^{2+}$ uptake, as induced by two stimuli.

Incubation procedures and ${ }^{45} \mathrm{Ca}^{3+}$ uptake: The first estimation of ${ }^{45} \mathrm{Ca}^{2+}$ uptake in the synaptosomes with high $\mathrm{KCl}$ was done by the method of Blaustein (18). The synaptosomes were first equilibrated in a physiological salt solution containing $132 \mathrm{mM} \mathrm{NaCl}, 5 \mathrm{mM}$ $\mathrm{KCl}, 1.2 \mathrm{mM} \mathrm{NaH} \mathrm{PO}_{4}, 1.3 \mathrm{mM} \mathrm{MgCl}$, 
$1.2 \mathrm{mM} \mathrm{CaCl}_{2}, 10 \mathrm{mM}$ glucose and $20 \mathrm{mM}$ Tris buffered to $\mathrm{pH} 7.4$ at $25^{\circ} \mathrm{C}$ by titration with maleic acid for $15 \mathrm{~min}$ at $30^{\circ} \mathrm{C}$. The uptake of ${ }^{45} \mathrm{Ca}^{2+}$ in the synaptosomes was initiated when $0.6 \mathrm{ml}$ of suspension was added to $0.6 \mathrm{ml}$ of pre-warmed high $\mathrm{KCl}$ solution containing $137 \mathrm{mM} \mathrm{KCl}, 1.2 \mathrm{mM}$ $\mathrm{NaH}_{2} \mathrm{PO}_{4}, 1.3 \mathrm{mM} \mathrm{MgCl}, 1.2 \mathrm{mM} \mathrm{CaCl} 2$ included ${ }^{45} \mathrm{Ca}^{2+}, 10 \mathrm{mM}$ glucose and $20 \mathrm{mM}$ Tris buffered to $\mathrm{pH} 7.4$ at $25^{\circ} \mathrm{C}$ by titration with maleic acid. Unless otherwise indicated, the final solution had $66 \mathrm{mM} \mathrm{NaCl} .71 \mathrm{mM}$ $\mathrm{KCl}, 1.2 \mathrm{mM} \mathrm{NaH} \mathrm{PO}_{4}, 1.3 \mathrm{mM} \mathrm{MgCl}$, $1.2 \mathrm{mM} \mathrm{CaCl}{ }_{2}$ (specific activity $2 \mathrm{mCl} / \mathrm{m}$ $\mathrm{mol}), 10 \mathrm{mM}$ glucose and $20 \mathrm{mM}$ Tris. The mixture was incubated for $2 \mathrm{~min}$ at $30^{\circ} \mathrm{C}$. unless otherwise indicated. When the effect of Aspaminol was examined, the drug was added at the beginning of the preincubation period. This experimental incubation was terminated by adding $1.2 \mathrm{ml}$ of ice-cold stopping solution containing $30 \mathrm{mM}$ ethyleneglycol-bis-( $\beta$-amino-ethylether) - N,N'-

tetraacetic acid (GEDTA), $120 \mathrm{mM} \mathrm{NaCl}$ and $5 \mathrm{mM} \mathrm{KCl}$ titrated to $\mathrm{pH} 7.4$ at $25^{\circ} \mathrm{C}$ with Tris base. One $\mathrm{ml}$ of mixture was immediately filtered by passing through a Millipore filter (HA, $0.45 \mu \mathrm{m}$ ) prewashed with ice-cold washing solution containing $132 \mathrm{mM}$ choline $\mathrm{Cl} .5 \mathrm{mM} \mathrm{KCl}, 1.2 \mathrm{mM}$ $\mathrm{NaH}_{2} \mathrm{PO}_{4}, 1.3 \mathrm{mM} \mathrm{MgCl}, 1.2 \mathrm{mM} \mathrm{CaCl}$, $10 \mathrm{mM}$ glucose and $20 \mathrm{mM}$ Tris buffered to $\mathrm{pH} 7.4$ at $25^{\circ} \mathrm{C}$ by titration with maleic acid, and washed twice with ono $\mathrm{ml}$ of icecold washing solution.

The second estimation of ${ }^{45} \mathrm{Ca}^{2+}$ uptake in the synaptosomes with ATP was done by the method of Guerrero-Munoz et al. (8). The synaptosomes were preincubated in $0.32 \mathrm{M}$ sucrose for $5 \mathrm{~min}$ at $30^{\circ} \mathrm{C}$. Tho uptake of ${ }^{45} \mathrm{Ca}^{2+}$ in the synaptosomes was initiated when $0.6 \mathrm{ml}$ of suspension was added to $0.6 \mathrm{ml}$ of prewarmed stimulator solution containing $0.1 \mathrm{~m} \mathrm{M} \mathrm{CaCl}$ including ${ }^{45} \mathrm{Ca}^{2+}$ (specific activity $2 \mathrm{mCi} / \mathrm{m}$ mol).
$3 \mathrm{mM} \mathrm{MgCl} 2.3 \mathrm{mM}$ ATP disodium salt and $50 \mathrm{mM}$ Tris buffered to pH 7.4 at $25^{\circ} \mathrm{C}$ by titration with maleic acid. At fixed intervals. ${ }^{45} \mathrm{Ca}^{2+}$ uptake was terminated by adding $1.2 \mathrm{ml}$ of ice-cold washing solution containing $100 \mathrm{mM} \mathrm{NaCl}, 0.1 \mathrm{mM} \mathrm{CaCl}_{2}, 3 \mathrm{mM}$ $\mathrm{MgCl}_{2}$ and $50 \mathrm{mM}$ Tris buffered to $\mathrm{pH} 7.4$ at $25^{\circ} \mathrm{C}$ by titration with maleic acid, and one $\mathrm{ml}$ of synaptosomal suspension was immediately passed through a Millipore filter (HA, $0.45 \mathrm{~km}$ ) prewashed with ice-cold washing solution. Each filter was washed twice with one $\mathrm{ml}$ of the same solution. The drug was added at the beginning of the preincubation period. The experimental incubation carried out at $30^{\circ} \mathrm{C}$.

To measure the retention of previously accumulated ${ }^{45} \mathrm{Ca}^{2+}, 0.5 \mathrm{ml}$ of the synaptosomes were preincubated in $0.32 \mathrm{M}$ sucrose for $5 \mathrm{~min}$ at $30^{\circ} \mathrm{C}$. followed by a $10 \mathrm{~min}$ incubation in the presence of $0.5 \mathrm{ml}$ of stimulator solution (final one $\mathrm{ml}$ ). These synaptosomes were then diluted with 10 volumes of pre-warmed washing solution and again re-incubated at $30^{\circ} \mathrm{C}$. After fixed time intervals between 0 to $10 \mathrm{~min}$, two $\mathrm{ml}$ of the synaptosomal suspension was immediately filtered and washed twice with one $\mathrm{ml}$ of ice-cold washing solution. When the effect of Aspaminol was examined, the drug was added at the beginning of the re-incubation period.

The radioactive $\mathrm{Ca}^{2+}$ retained was estimated by a liquid scintillation spectrometer, after the filters had been dissolved in a toluene scintillator. The values wero corrected for the ${ }^{45} \mathrm{Ca}^{2+}$ remaining on the filters in the absence of the synaptosomal fraction. ${ }^{45} \mathrm{Ca}^{2+}$ uptake was estimated from the radioactivity of the filter. Protein was determined by the method of Lowry et al. (19), using bovine serum albumin as the standard. The amount of protein contained in the incubation mixture was 300 to $600 \mathrm{~kg} / \mathrm{ml}$. 
Assessment of analgesia: Male Wistar strain rats, weighing 30 to $40 \mathrm{~g}$ and 70 to $90 \mathrm{~g}$. were used. Subcutaneous doses of Aspaminol $(100 \mathrm{mg} / \mathrm{kg}$ and $500 \mathrm{mg} / \mathrm{kg}$ ) or morphine $(2.5 \mathrm{mg} / \mathrm{kg})$ were administered. and assessed using the Randall Sellito test (20).

In the Randall Sellito test (Analgesymeter. Ugo Basile) a force increasing at a constant rate is applied force to the rat hindpaw. The applied force is continuously monitored by an indicator moving along a linear scale calibrated in grams. The application of force is stopped when rats start to struggle to a noticeable degree.

Drugs used: Aspaminol (1.1-diphenyl-3piperidinobutanol hydrochloride: Kowa). morphine hydrochloride (Sankyo), Tris (Tris (hydroxymethyl) aminomethane and ATP disodium salt; Sigma), HEPES (N-2hydroxyethyl-piperazine-N'-2 ethanesulfonic acid: Nakarai), GEDTA (ethyleneglycol-bis( $\beta$-amino-ethylether)-N,N'-tetraacetic acid; Wako-Junyaku). Ficoll 400 (Pharmacia Fine Chemicals) and ${ }^{45} \mathrm{CaCl}_{2}$ (specific activity: $16 \mathrm{mCi} / \mathrm{mg}$ : New England Nuclear). Other chemicals used were of analytical grade. Drugs were dissolved in double-distilled and deionized water

\section{RESULTS}

Effect of Aspaminol on potassium stimulated calcium uptake in the synaptosomes: Figure 1 shows the uptake of calcium in the depolarized (71 $\mathrm{mM} \mathrm{KCl}$ ) and polarized ( $5 \mathrm{mM} \mathrm{KCl}$ ) synaptosomes, as a function of time. The uptake of calcium increased linearly for approximately the first minute of incubation in the polarized synaptosomes, and reached a plateau level within $2 \mathrm{~min}$. In the presence of $71 \mathrm{mM} \mathrm{KCl}$, both the rate of uptake and plateau value were increased. Potassium stimulated calcium uptake, which was calculated as difference between the uptakes in $71 \mathrm{mM} \mathrm{KCl}$ and $5 \mathrm{mM}$
$\mathrm{KCl}$ at the plateau level, was about $6 \mu \mathrm{mol} / \mathrm{g}$ protein. This value was in good agreement with that reported by other investigators (12.

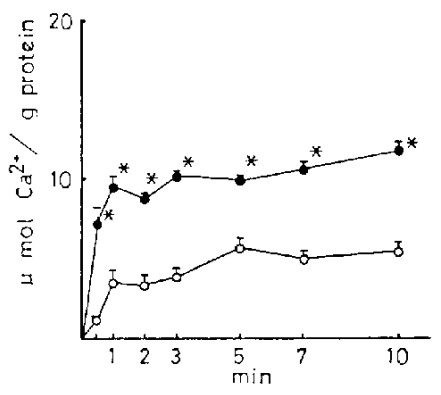

Fig. 1. Calcium accumulation as a function of different incubation times for depolarized and polarized synaptosomes. Each point represents mean \pm S.E. of 3 experiments. Synaptosomes were equilibrated in the physiological salt solution for $15 \mathrm{~min}$ at $30^{\circ} \mathrm{C}$. The incubation was initiated by addition of high $\mathrm{KCl}(137 \mathrm{mM})$ or physiological sait solution containing ${ }^{45} \mathrm{Ca}^{2+}$. and terminated by addition of ice-cold GEDTA stopping solution and rapid filtration after fixed intervals. O: depolarized synaptosomes. O: polarized synaptosomes. *; significantly different from the polarized synaptosomes at $\mathrm{P}<0.05$.

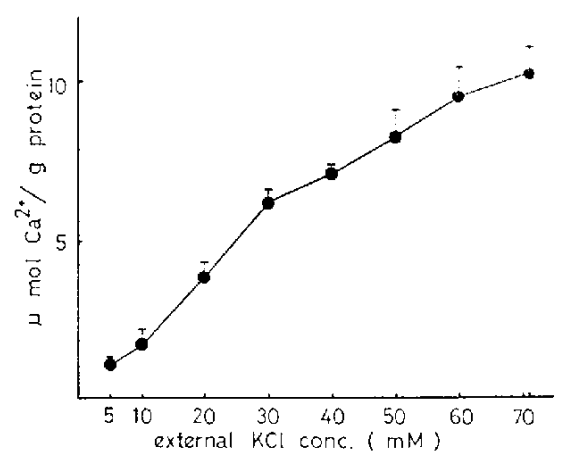

Fig. 2. Calcium accumulation as a function of different concentration of external potassium. Each point represents meantS.E. of 3 experiments. Synaptosomes were equilibrated in the physiological salt solution for $15 \mathrm{~min}$ at $30^{\circ} \mathrm{C}$. The incubation was initiated by addition of different concentration of high $\mathrm{KCl}$ solution containing ${ }^{45} \mathrm{Ca}^{2+}$, and terminated by addition of ice-cold GEDTA stopping solution and rapid filtration after $2 \mathrm{~min}$. 
21). Figure 2 shows the calcium uptake in the synaptosomes as a function of different concentrations of external potassium. An increase of external potassium stimulated the calcium uptake in the synaptosomes up to $71 \mathrm{mM} \mathrm{KCl}$. This results was in good agreement with that reported by Blaustein (18). From these results, an incubation time of $2 \mathrm{~min}$ and a concentration of $71 \mathrm{mM} \mathrm{KCl}$ were used in subsequent studies on potassium stimulated calcium uptake in the synaptosomes.

Figure 3 shows the effect of Aspaminol on potassium stimulated calcium uptake in the synaptosomes. The calcium uptake in $5 \mathrm{mM}$ $\mathrm{KCl}$ medium was not influenced significantly by various concentrations $\left(10^{-6}\right.$ to $\left.10^{-4} \mathrm{M}\right)$ of Aspaminol (Fig. 3, lower curve), but potassium stimulated calcium uptake was inhibited by Aspaminol in a concentration dependent manner (Fig. 3, upper curve).

Since Aspaminol inhibits the calcium uptake in the microsomal fractions from smooth muscle and this inhibition is abolished by the increase of calcium concentration in the reaction mixture (16), it was of interest to determine whether or not Aspaminol is acting as a competitive or noncompetitive inhibitor in calcium uptake. Therefore, we tested the inhibitory effect of Aspaminol on calcium uptake at different external concentrations of calcium. Table 1 shows that Aspaminol $\left(10^{-4} \mathrm{M}\right)$ inhibited the potassium

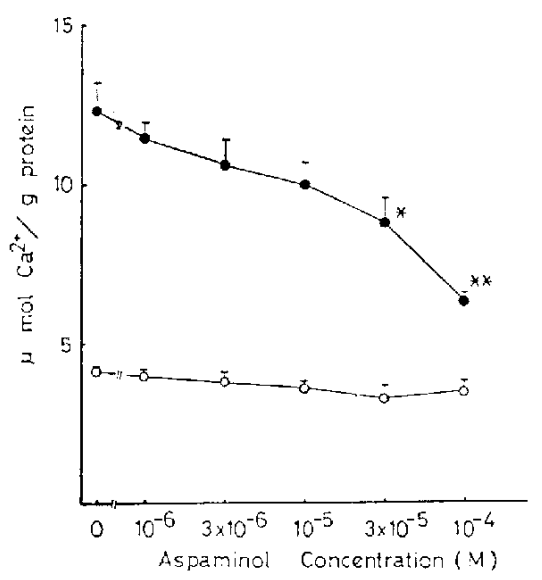

Fig. 3. Effect of various concentration of Aspaminol on potassium stimulated calcium uptake in the synaptosomes. Each point represents mean \pm S.E. of 5 experiments. Synaptosomes were equilibrated in the physiological salt solution in the presence of different concentration of Aspaminol for $15 \mathrm{~min}$ at $30^{\circ} \mathrm{C}$. The incubation was initiated by addition of high $\mathrm{KCl}(137 \mathrm{mM})$ or physiological salt solution containing ${ }^{45} \mathrm{Ca}^{2+}$ in the presence of various concentration of Aspaminol, and terminated by addition of icecold GEDTA stopping solution and rapid filtration after 2 min. O: depolarized synaptosomes. $O$; polarized synaptosomes. " significantly different from the control at $\mathrm{P}<0.05$ and $P<0.01$, respectively.

Table 1. Effect of Aspaminol on potassium stimulated calcium uptake at different external calcium concentration

\begin{tabular}{ccc}
\hline $\begin{array}{c}\mathrm{CaCl}_{2} \\
\text { (Conc.) }\end{array}$ & \multicolumn{2}{c}{$\begin{array}{c}{ }^{45} \mathrm{Ca} \text { Uptake }(\mu \text { mol/g protein) } \\
\text { Aspaminol }\left(10^{-4} \mathrm{M}\right)\end{array}$} \\
\hline $0.12 \mathrm{mM}$ & $2.44 \pm 0.19$ & $1.60 \pm 0.07^{*}$ \\
$0.36 \mathrm{mM}$ & $5.20 \pm 0.30$ & $3.51 \pm 0.21^{*}$ \\
$1.2 \mathrm{mM}$ & $10.67 \pm 0.76$ & $6.30 \pm 0.32^{*}$ \\
$3.6 \mathrm{mM}$ & $15.97 \pm 0.56$ & $13.40 \pm 1.04$ \\
$12.0 \mathrm{mM}$ & $20.94 \pm 3.23$ & $18.93 \pm 0.80$ \\
\hline
\end{tabular}

Each value represents mean \pm S.E. of 5 experiments. Synaptosomes were equilibrated in the physiological salt solution containing various concentration of $\mathrm{CaCl}_{2}$ in the presence and absence of $10^{-4} \mathrm{M}$ Aspaminol for $15 \mathrm{~min}$ at $30^{\circ} \mathrm{C}$. The incubation was initiated by addition of high $\mathrm{KCl}(137 \mathrm{mM})$ salt solution containing various concentration of $\mathrm{CaCl}_{2}$ in the presence and absence of $10^{-4} \mathrm{M}$ Aspaminal, and terminated by addition of ice-cold GEDTA stopping solution and rapid filtration after 2 min. ${ }^{*}$ significantly different from the control at $P<0.01$. 
stimulated calcium uptake in the low external calcium up to $1.2 \mathrm{mM}$. but this inhibitory effect was abolished by high external calcium concentrations ( $3.6 \mathrm{mM}$ to $12 \mathrm{mM}$ ). Figure 4 shows the Lineweaver-Burk plots for the above data. The reciprocal plots gave hyperbolic curves, but, in case of higher concentrations of calcium, it was apparent that the lines extrapolated to the same calcium concentration. indicating that Aspaminol inhibited the calcium uptake competitively.

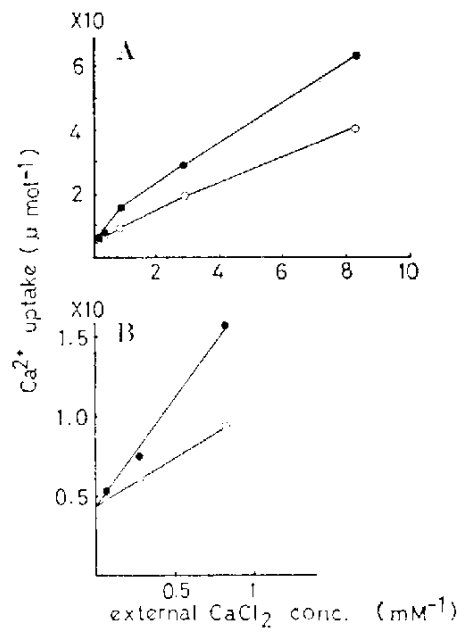

Fig. 4. (A): Lincwoaver-Burk plots of Aspaminol actions on potassium stimulated calcium uptake at different external calcium concentrations, (B); same plots at high concentration of external calcium. $O$ : Aspaminol $\left(10^{-4} \mathrm{M}\right)$. O: control.
Effect of Aspaminol on ATP stimulated calcium uptake in the synaptosomes: Table 2 shows that ATP stimulated calcium uptake was extremely low in the absence of ATP and/or $\mathrm{Mg}^{2+}$. Figure 5 shows the calcium uptake data obtained with synaptosomes preincubated with various concentrations of

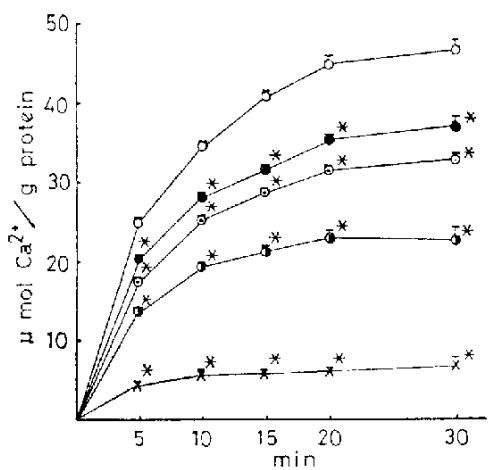

Fig. 5. Effect of various concentration of Aspaminol on ATP stimulated calcium uptake in the synaptosomes. Each point represents mean $\pm S$.E. of 4 experiments. Synaptosomes were suspended with $0.32 \mathrm{M}$ sucrose and preincubated in the presence of various concentration of Aspaminol for 5 min at $30^{\circ} \mathrm{C}$. The incubation was initiated by addition of uptake solution containing ${ }^{46} \mathrm{Ca}^{2+}$ in the presence of various concentrations of Aspaminol, and terminated by rapid filtration after fixed intervals. C: control. : $10^{-6} \mathrm{M}$ Aspaminol. $\odot: 10^{-5} \mathrm{M}$ Aspaminol, $0: 10^{-4} \mathrm{M}$ Aspaminol, $x$; ATP omitted. * significantly different from the control at $\mathrm{P}<0.01$

Table 2. Effects of components of reaction mixture on ATP stimulated calcium uptake in the synaptosomes

\begin{tabular}{lc}
\hline Addition & ${ }^{45} \mathrm{Ca}$ Uptako $(\mu$ mol/g protein) \\
Complete & $19.70 \pm 1.78$ \\
-ATP. - Mg ${ }^{2+}$ & $4.68 \pm 0.38^{*}$ \\
-ATP & $3.82 \pm 0.21^{*}$ \\
- Mgg & $5.11 \pm 0.57^{*}$ \\
\hline
\end{tabular}

Each value represonts mean \pm S.E. of 4 to 5 experiments. Synaptosomes were suspended with $0.32 \mathrm{M}$ sucrose and proincubated for $2 \mathrm{~min}$ at $30^{\circ} \mathrm{C}$. The incubation was initiated by addition of uptake solution containing ${ }^{45} \mathrm{Ca}^{2-}$ in the presence of $3 \mathrm{mM} \mathrm{ATP} \mathrm{and}$ /or $3 \mathrm{mM} \mathrm{MgCl}$. The incubation terminated by rapid filtration after $10 \mathrm{~min}$. "significantly different from the complete group at $P<0.01$. 


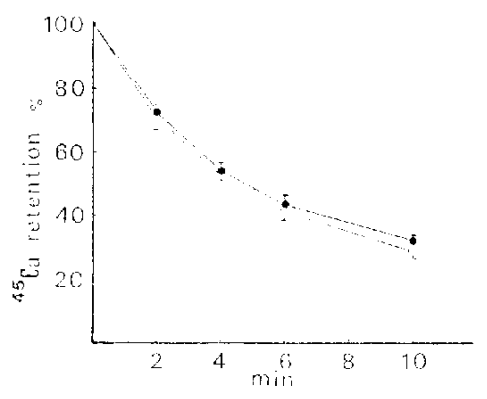

Fig. 6. Time course of calcium retension by synaptosomes. Each point represents mean \pm S.E. of 4 experiments. Synaptosomes were preincubated for $5 \mathrm{~min}$ at $30^{\circ} \mathrm{C}$, and then loaded with uptake solution for $10 \mathrm{~min}$ at $30^{\circ} \mathrm{C}$. The incubation was initiated by addition of 10 volume of washing solution containing $100 \mathrm{mM}$ $\mathrm{NaCl}, 3 \mathrm{mM} \mathrm{MgCl}, 0.1 \mathrm{mM} \mathrm{CaCl}$ and $50 \mathrm{mM}$ Tris-maleic acid buffer, and terminated by rapid filtration after fixed intervals. $O$ : control, Aspaminol $\left(10^{-4} \mathrm{M}\right)$.

Aspaminol $\left(10^{-6}\right.$ to $\left.10^{-4} \mathrm{M}\right)$. ATP stimulated calcium uptake in the synaptosomes showed a rapid phase and followed by a slower phase which reached a plateau level in about $20 \mathrm{~min}$. Aspaminol significantly reduced the rate of uptake and maximal level of synaptosomal calcium, in a concentration dependent manner.

The effect of Aspaminol $\left(10^{-4} \mathrm{M}\right)$ on the time-dependent release of ${ }^{45} \mathrm{Ca}^{2+}$ from ${ }^{45} \mathrm{Ca}^{2+}$-loaded synaptosomes is shown in Fig. 6. From 2 to $10 \mathrm{~min}$. Aspaminol did not appear to have any effect on the rate of ${ }^{45} \mathrm{Ca}^{2+}$ release. These results suggest that the inhibitory effect of Aspaminol is mainly due to inhibition of calcium influx, but not to acceleration of calcium efflux.

Assessment of analgesia: In case of 5 weeks old rats, morphine $(2.5 \mathrm{mg} / \mathrm{kg}$ s.c.) had an analgesic effect and mean threshold force to elicit struggle of the paw was $160 \pm 24$ $g$ (mean \pm S.E.) at $30 \mathrm{~min}$ after administration. This value was significantly higher than the control value $(92 \pm 11 \mathrm{~g})$ at the same time after administration, but Aspaminol (500 $\mathrm{mg} / \mathrm{kg} \mathrm{s.c.)} \mathrm{did} \mathrm{not} \mathrm{have} \mathrm{an} \mathrm{analgesic}$
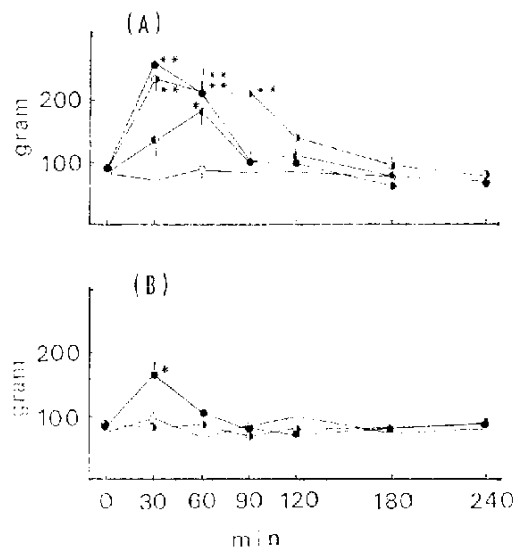

Fig. 7. Effects of Aspaminol and morphine on pawpinch test in rats. Each point represents mean $\pm S$.E. of 5 to 6 rats. [A]; weanling rats. [B]: 5 weeks old rats, $O$ : controi (saline s.c.). - morphine (2.5 mg/kg s.c.). (Aspaminol (500 mg/kg s.c.). C: Aspaminol (100 mg/kg s.c.). * ${ }^{* *}$ significantly different from tho control at $P<0.05$ and $P<0.01$, respectively.

effect at cach time after administration (Fig. 7-B). On the other hand, combined administration of Aspaminol (500 $\mathrm{mg} / \mathrm{kg} \mathrm{s.c.)} \mathrm{with}$ morphine $(2.5 \mathrm{mg} / \mathrm{kg}$ s.c.) potentiated the analgesic effect of morphine (data not shown). In case of weanling rats (about 3 weeks old), morphine (2.5 $\mathrm{mg} / \mathrm{kg} \mathrm{s.c.)}$ and Aspaminol $(500 \mathrm{mg} / \mathrm{kg} \mathrm{s.c.} \mathrm{and} 100 \mathrm{mg} / \mathrm{kg}$ s.c.) also induced an analgesic effect. The peak value of threshold force after administration of morphine was $250 \mathrm{~g}$ at $30 \mathrm{~min}$, and that of Aspaminol $(500 \mathrm{mg} / \mathrm{kg} \mathrm{s.c.} \mathrm{and}$ $100 \mathrm{mg} / \mathrm{kg} \mathrm{s.c.)}$ were $230 \pm 20 \mathrm{~g}$ at $30 \mathrm{~min}$ and $184 \pm 28 \mathrm{~g}$ at $60 \mathrm{~min}$, respectively. These values were significantly higher than the corresponding control values (Fig. 7-A).

\section{DISCUSSION}

Verapamil and D 600 which have been shown to prevent the influx of calcium in the smooth muscle (13) and its microsomal fractions (14) inhibited the potassium stimulated calcium uptake in rat brain synaptosomes (11-12). Aspaminol (1.1- 
diphenyl-3-piperidinobutanol hydrochloride). a nonspecific smooth muscle relaxant, also inhibited the calcium uptake in the smooth muscle (15) and its microsomal fractions (14. 16). Therefore, we attempted to determine whether or not Aspaminol also would inhibit the calcium uptake in rat brain synaptosomes. For this purpose, we assured the extent of calcium uptake in the synaptosomes using high $\mathrm{KCl}$ and ATP.

Our results showed that Aspaminol clearly inhibited the synaptosomal calcium uptake by two stimuli. The inhibition was observed during the initial rate as well as in the maximal calcium uptake. The concentration of Aspaminol $\left(10^{-4} \mathrm{M}\right)$ required to block the uptake by about two-thirds in the maximal calcium uptake by two stimuli. Since the inhibitions of the various stimuli-induced calcium uptake were shown to same degree, Aspaminol also would act on the surfaces of the synaptosomal membranes as well as that of smooth muscle (16) and also inhibited the high $\mathrm{KCl}$ induced calcium uptake in the synaptosomes competitively against the extracellular calcium concentration.

The recent findings showed that morphine blocked calcium uptake in the synaptosomes (8-10). Because calcium is so intimately coupled with exocytotic release of neurotransmitters (22), a process as stimulussecretion coupling, these findings suggest that morphine may inhibit calcium-mediated "stimulus-secretion coupling" events to cause analgesic response. To make this hypothesis clear, we carried out the paw pinch test in the rats treated with Aspaminol because this drug markedly inhibited the calcium uptake in the synaptosomes. In case of weanling rats, Aspaminol slightly but significantly affected the responses in the paw pinch test. Furthermore, we tested the combined administration of Aspaminol with morphine. Aspaminol clearly potentiated the analgesic effect of morphine. These results suggest that a certain relationship may exist between the analgesic effect and calcium movement on the nerve endings. But Aspaminol has virtually no effects on the analgesic responses in adult rats. This discrepancy is still obscure. One of possible mechanisms is considered. Since most of Aspaminol molecules exist as ion forms in the physiological $\mathrm{pH}$ (pKa of Aspaminol: 8.62), these molecules may be difficult to pass through the blood-brain barrier and can not reach a sufficient concentration for the analgesic responses in the rat brain, though further study is required.

\section{REFERENCES}

1) Katz, B. and Miledi, R.: lonic requirements of synaptic transmitter release. Nature 215, 651 (1967)

2) Blaustein, M.P. and Goldberg, J.M.: Membrane potentials in pinched-off presynaptic nerve terminals monitored with a fluorescent probe: Evidence that synaptosomes have potassium diffusion potentials. J. Physiol. 247, 589-615 (1975)

3) Blaustein, M.P. and Wiesman, W.P.: Effect of sodium ions on caicium movements in isolated synaptic terminals. Proc. natn. Acad. Sci U.S.A. 66, 664-671 (1970)

4) Bradford, H.F.: Respiration in vitro of synaptosomes mammalian cerebral cortex. J Neurochem. 16, 675-684 (1969)

5) Bradford, H.F. and Thomas, A.J.: Metabolism of glucose and glutamate from mammalian cerebral cortex. J. Neurochem. 16, 1495-1504 (1969)

6) Kaneto, H.: Inorganic ions: The role of calcium. Narcotic Drugs, Edited by Clouet, D.H., p. 300309, Plenum Press, New York (1971)

7) Harris, R.A., Loh, H.H. and Way, E.L.: Effects of divalent cations, cation chelators and an ionophore on morphine analgesia and tolerance. J. Pharmacol. exp. Ther. 195, 488-498 (1975)

8) Guerrero-Munoz, F., Cerreta, K.V., Guirrero, M.L. and Way, E.L.: Effect of morphine on synaptosomal Ca uptake. J. Pharmacol. exp. Ther. 209, 132-136 (1979)

9) Guerrero-Munoz, F., Guirrero, M.L. and Way, E.L.: Effect of morphine on calcium uptake by lysed synaptosomes. J. Pharmacol. exp. Ther. $211,370-374$ (1979)

10) Ross, D.H.: Effects of opiate drugs on the metabolism of calcium in synaptic tissue: 
Calcium in Drug Action, Edited by Weiss, G.B. p. 241-259. Plenum Press. New York (1978)

11) Nachshen, D.A. and Braustein, M.P.: The effects of some organic calcium antagonists on calcium influx in presynaptic nerve terminals. Mol. Pharmacol. 16, 579-586 (1979)

12) Ichida, S., Okada, K. and Terao, M.: Effect of verapamil on ${ }^{45} \mathrm{Ca}$ uptake by synaptosomes. Japan. J. Pharmacol. 30, 207-211 (1980)

13) Rosenberger, $L$, and Triggle, D.J.: Calcium. calcium translocation and specific calcium antagonists. Calcium in Drug Action, Edited by Weiss, G.B. p. 3-31, Plenum Press. New York (1978)

14) Takayanagi, I., Hisayama, T. and Suzuki, S.: Effects of nonspecific muscle relaxants and Ca-blocker on Ca-release and Ca-binding in microsomal fractions from rabbit taenia coli. Japan. J. Pharmacol. 30, 641-646 (1980)

15) Takayanagi, I., Karasawa, A. and Kasuya, Y.: Relaxation of depolarized guinea pig taenia caecum induced by antispasmodics. Europ. J. Pharmacol. 50, 137-143 (1978)

16) Takayanagi, I., Hisayama, T., Yosida, Y. and Koike, K.: Effects of nonspecific smooth muscle relaxants on calcium-uptake by microsomal fraction and their inhibitory action in rabbit taenia coli. J. Pharm. Dyn. 3, 160-166 (1980)

17) Cotman, C.W. and Matthews, D.A.: Synaptic plasma membranes from rat brain synaptosomes: Isolation and partial characterization. Biochim. Biophys. Acta 249, 380-394 (1971)

18) Blaustein, M.P.: Effects of potassium, veratridine and scorpion venom on calcium accumulation and transmitter release by nerve terminals in vitro. J. Physiol. 247, 617-655 (1975)

19) Lowry, O.H., Rosebrough, N.J., Farr, A.L. and Randall, R.U.: Protein measurement with the Folin phenol reagent. J. biol. Chem. 193, 265275 (1951)

20) Randall, L.O. and Sellito, J.J.: A method for measurement of analgesic activity on inflammed tissue. Archs int. Pharmacodyn. Thér 111. 409-419 (1957)

21) Ichida, S., Yonehara, N., Watanabe, Y. and Yosida, H.: Inhibitory effect of dibutyryl cyclic GMP on potassium-stimulated ${ }^{45} \mathrm{Ca}$ uptake by synaptosomes from rat brain. Brain research 192, 487-494 (1980)

22) Rubin, R.P.: The role of calcium in the release of ncurotransmitter substances and hormons. Pharmacol. Rev. 22, 389-428 (1970) 